\title{
A new species of Djalmabatista Fittkau (Chironomidae, Tanypodinae) from Mato Grosso, Brazil
}

\author{
Linn Katrine Hagenlund ${ }^{1}$, Trond Andersen ${ }^{1} \&$ Humberto Fonseca Mendes $^{1,2}$ \\ ${ }^{1}$ Department of Natural History, Bergen Museum, University of Bergen, \\ PO Box 7800, N-5020, Bergen, Norway, \\ e-mail:linn.hagenlund@student.uib.no,trond.andersen@zmb.uib.no \\ ${ }^{2}$ Corresponding author: Humberto Fonseca Mendes, e-mail: humberto.mendes@bm.uib.no
}

HAGENLUND, L.K., ANDERSEN, T. \& MENDES, H.F. A new species of Djalmabatista Fittkau (Chironomidae, Tanypodinae) from Mato Grosso, Brazil. Biota Neotrop. 10(3): http://www.biotaneotropica.org.br/v10n3/en/ abstract?article+bn04210032010.

Abstract: Djalmabatista scopulata sp. n. is described and figured as male imago, based on material collected in a light trap in Mato Grosso, Brazil. The new species groups with Djalmabatista ivanyae Fittkau, 1968 by having a projection with apical brush on the inner margin of the gonocoxite; it can be separated from D. ivanyae on the banded abdomen.

Keywords: Chironomidae, Tanypodinae, Procladiini, Djalmabatista, new species, Neotropical region.

HAGENLUND, L.K., ANDERSEN, T. \& MENDES, H.F. Uma nova espécie de Djamabatista Fittkau (Chironomidae, Tanypodinae) do Estado do Mato Grosso, Brasil. Biota Neotrop. 10(3): http://www. biotaneotropica.org.br/v10n3/pt/abstract?article+bn04210032010.

Resumo: Djalmabatista scopulata sp. n. é descrita e ilustrada com base no macho adulto de material coletado em armadilha luminosa no Estado do Mato Grosso, Brasil. Esta nova espécie se aproxima de Djalmabatista ivanyae Fittkau, 1968 pela projeção de pelos na margem interna do gonocoxito, da qual pode ser separada com base no padrão de coloração do abdomen.

Palavras-chave: Chironomidae, Tanypodinae, Procladiini, Djalmabatista, espécie nova, região Neotropical. 


\section{Introduction}

The genus Djalmabatista was described by Fittkau (1968) for five species from the Amazon area in Brazil. Later, three additional species have been described from the Neotropical region (Paggi 1985, Carraro et al. 1992, Oliveira \& Carraro 1997). Prothentes pulcher Johannson, 1908 from North and South America; Procladius (Calotanypus) bifida Chaudhuri et Debnath, 1983 from India and Procladius (Psilotanypus) reidi Freeman, 1955 from the Palaearctic, Afrotropical and Oriental regions have been transferred to the genus (see Ashe \& O'Connor 2009). The genus has also been recorded from Australia (Cranston \& Martin 1989). Recently, D. maillardi Doitteau et Nel, 2007 was described from early Eocene amber in France.

The genus belongs to the tribe Procladiini and is related to the genus Procladius Skuse. However, Djalmabatista is generally easily recognized on the striking color patterns on the thorax, abdomen and legs and the iridescent eyes. The larvae are known to inhabit lakes, ponds and slow flowing rivers. In the Neotropical Region larvae appear to live predominantly in rivers.

Below we describe a new species of Djalmabatista from Mato Grosso in Brazil resembling D. ivanyae Fittkau, 1968 by having a projection with apical brush on the inner margin of the gonocoxite. It can readily be separated from $D$. ivanyae on the color pattern of the abdomen; while $D$. ivanyae has a pale abdomen, the abdomen of the new species has a distinct dark brown pattern.

\section{Material and Methods}

The specimens were mounted on slides in Canada balsam following the procedure outlined by Sæther (1969). The general terminology follows Sæther (1980). The measurements are given as ranges. The color is described based on cleared, slide-mounted specimens.

The holotype is deposited in the Museu de Zoologia da Universidade de São Paulo (MZUSP), São Paulo, Brazil; the paratype in the Department of Natural History, Bergen Museum (ZMBN), University of Bergen, Bergen, Norway.

\section{Djalmabatista Fittkau}

Djalmabatista Fittkau, 1968: 328.

Djalmabatista Fittkau; Roback \& Coffman (1977: 49), Roback \& Tennessen (1978: 11), Roback (1989: 73).

Djalmabastica: incorrect subsequent spelling. (See Ashe \& O'Connor 2009: 154 for details).

Calotanypus Roback, 1971: 152, as subgenus of Procladius Skuse, 1889; type species: Protenthes pulcher Johannsen, 1908, by original designation. Synonymized with Djalmabatista Fittkau, 1968, by Roback \& Tennessen (1978: 17).

\section{Type species}

Djalmabatista director Fittkau, 1968: 332, by original designation.

\section{Other included species}

Djalmabatista amancii Fittkau, 1968: 344; Amazonas, Brazil. Djalmabatista antonii Fittkau, 1968: 335; Amazonas, Brazil. Djalmabatista bifida (Chaudhuri et Debnath, 1983: 115), as Procladius (Calotanypus). India.

Djalmabatista dellomei Fittkau, 1968: 342; Pará, Brazil.

Djalmabatista ivanyae Fittkau, 1968: 340; Amazonas, Brazil.

Djalmabatista lacustris Paggi, 1985: 75; Argentina.

Djalmabatista maillardi Doitteau et Nel, 2007: 12; France: early Eocene amber.
Djalmabatista orlandoi Oliveira et Carraro, 1997: 3; São Paulo, Brazil.

Djalmabatista pulchra (Johannsen, 1908: 273), as Prothentes. Brazil, ?Costa Rica, ?Guatemala, ?Mexico, ?Nicaragua; Canada, U.S.A.

Djalmabatista reidi (Freeman, 1955: 61), as Procladius (Psilotanypus). Saudi Arabia, United Arab Emirates; Cameroon, Chad, Ghana, Guinea, Sudan, Togo; India.

Djalmabatista scopulata sp. n.; Mato Grosso, Brazil.

Djalmabatista travassoi Carraro, Oliveira et Rego, 1992: 57; Rio de Janeiro, Brazil.

Generic diagnoses for males, females and pupae are given by Fittkau (1968), Fittkau \& Murray (1986), Murray \& Fittkau (1989) and Sæther \& Andersen (2000); for larvae by Roback \& Tennessen (1978) and Fittkau \& Roback (1983).

\section{Djalmabatista scopulata sp. n. (Figures 1-9)}

Type material: Holotype male, BRAZIL: Mato Grosso State: Nova Xavantina, Fazenda Sr. Queté, Córrego Cachoeira, $14^{\circ} 32.817^{\prime}$ S, 52³1.395'W, 16.X.2007, light trap, Luiz C. Pinho et al. leg (MZUSP). Paratype: 1 male, same data as holotype (ZMBN).

Diagnostic characters: The species can be distinguished from all other Djalmabatista species except $D$. ivanyae by the presence of a projection with apical brush on the inner margin of the gonocoxite. The banded abdomen separates it from D. ivanyae, which has a pale abdomen.

Etymology: From Latin scopa, broom and the suffix -atus, equipped with, referring to the brush on the inner margin of the gonocoxite.

Male $(\mathrm{n}=1-2)$. Total length 3.09-3.27 mm. Wing length $1.33-1.39 \mathrm{~mm}$. Total length / wing length 2.23-2.46. Wing length / length of profemur 2.28-2.37.

Coloration: Head and palps pale brown. Thorax pale with dark brown, confluent vittae, median anepisternum, preepisternum and postnotum. Legs with femur and tibia brown, all tarsi pale brown. Wing with blackish brown spot over RM and slightly paler spot over $\mathrm{MCu}$. Abdomen yellowish with distinct dark brown pattern on tergites I-VII, hypopygium dark brown, gonostylus blackish brown (Figure 3).

Head: AR 1.49-1.55. With 14 flagellomeres, ultimate flagellomere 161-162 $\mu \mathrm{m}$ long. Temporal setae 11-13, uniserial to irregularly biserial posteriorly. Clypeus with 8-13 setae. Tentorium 150-159 $\mu \mathrm{m}$ long, 25-27 $\mu \mathrm{m}$ wide. Stipes not measurable. Palpomere lengths / widths (in $\mu \mathrm{m}$ ): 39-45 / 30-33, 54-61 / 18-32, 84-86/27, 114-116/23-25, 168/18. No sensillae on third palpomere. Eye-elongation long, narrow, with rows of 2-3 ocelli (Figure 1).

Thorax: Antepronotum with 3-6 setae. Acrostichals 12, dorsocentrals 8-9, prealars 4-5, supraalar 0-1. Scutellum with 9 setae.

Wing (Figure 2): VR 1.30-1.39. Costal extension $121 \mu \mathrm{m}$ long. Brachiolum with 1 seta, costal extension with 8-14 non-marginal setae, $\mathrm{R}$ with $17-18$ setae, $\mathrm{R}_{1}$ with $13, \mathrm{R}_{4+5}$ with $17-18, \mathrm{M}_{1+2}$ with $3-9, M_{3+4}$ with $11-14, \mathrm{Cu}$ with $1-2, \mathrm{Cu}_{1}$ with $5-6$, remaining veins bare. Squama with 15-16 setae. Cell $\mathrm{r}_{4+5}$ with 51-62 setae, $\mathrm{m}_{1+2}$ with $10-15$ setae, remaining cells bare.

Legs: Spur of fore tibia 34-40 $\mu \mathrm{m}$ long, with 3-5 inner denticles; spurs of mid tibia 41-45 and 25-29 $\mu \mathrm{m}$ long, with 5 and 3 inner denticles, respectively; spurs of hind tibia 48-49 and 25-27 $\mu \mathrm{m}$ long, with 4-5 and 3 inner denticles, respectively. Width at apex of fore tibia 36-45 $\mu \mathrm{m}$, of mid tibia $42-43 \mu \mathrm{m}$, of hind tibia $44-45 \mu \mathrm{m}$. 


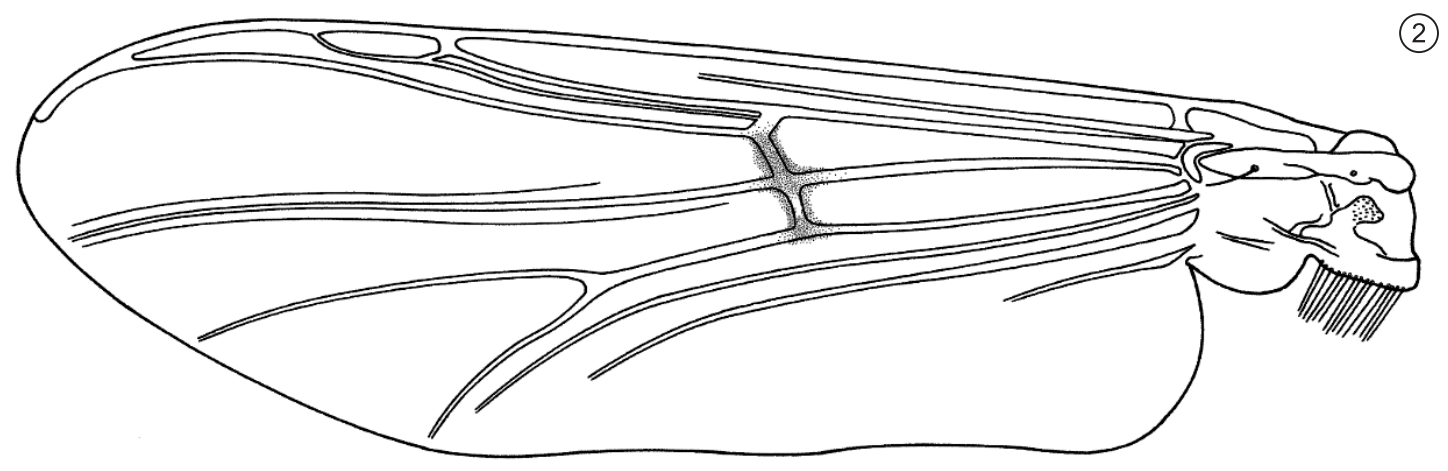

(3)
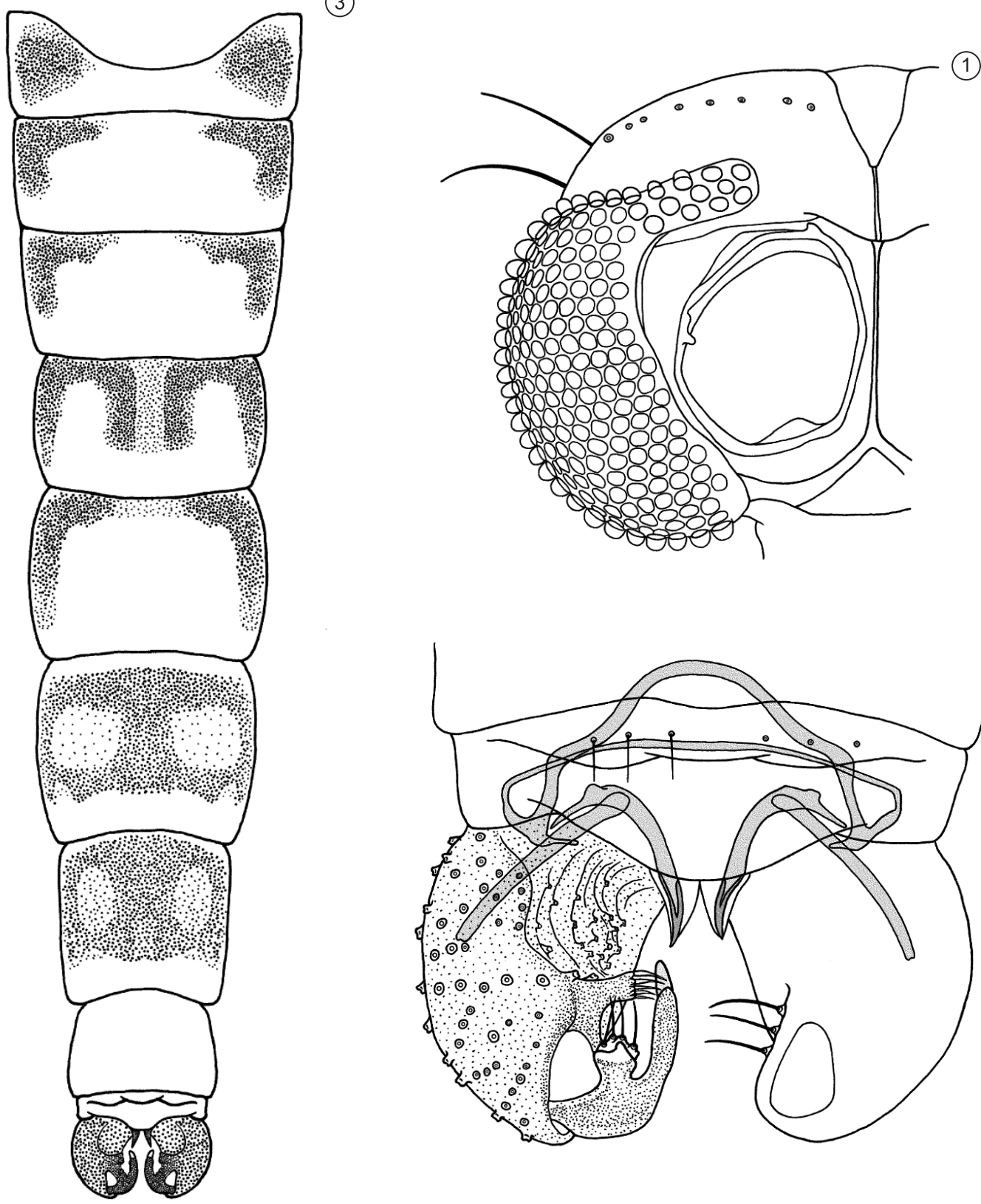

(4)

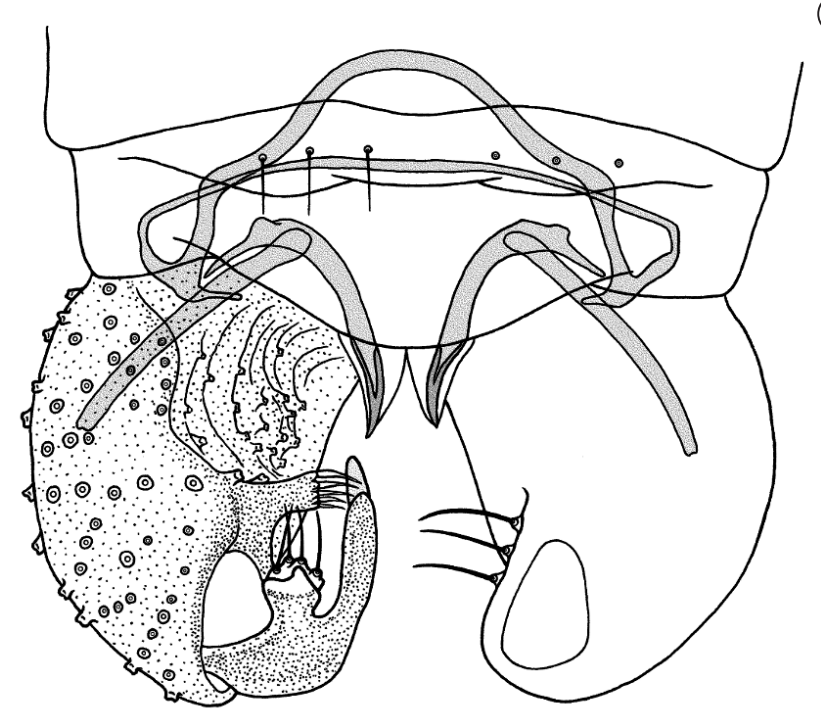

Figures 1-4. Djalmabatista scopulata sp. n., male. 1) Head; 2) Wing, setae on cells and membrane omitted (except for brachiolum and squama); 3) Abdomen; and 4) Hypopygium showing the apodemes, dorsal view. 


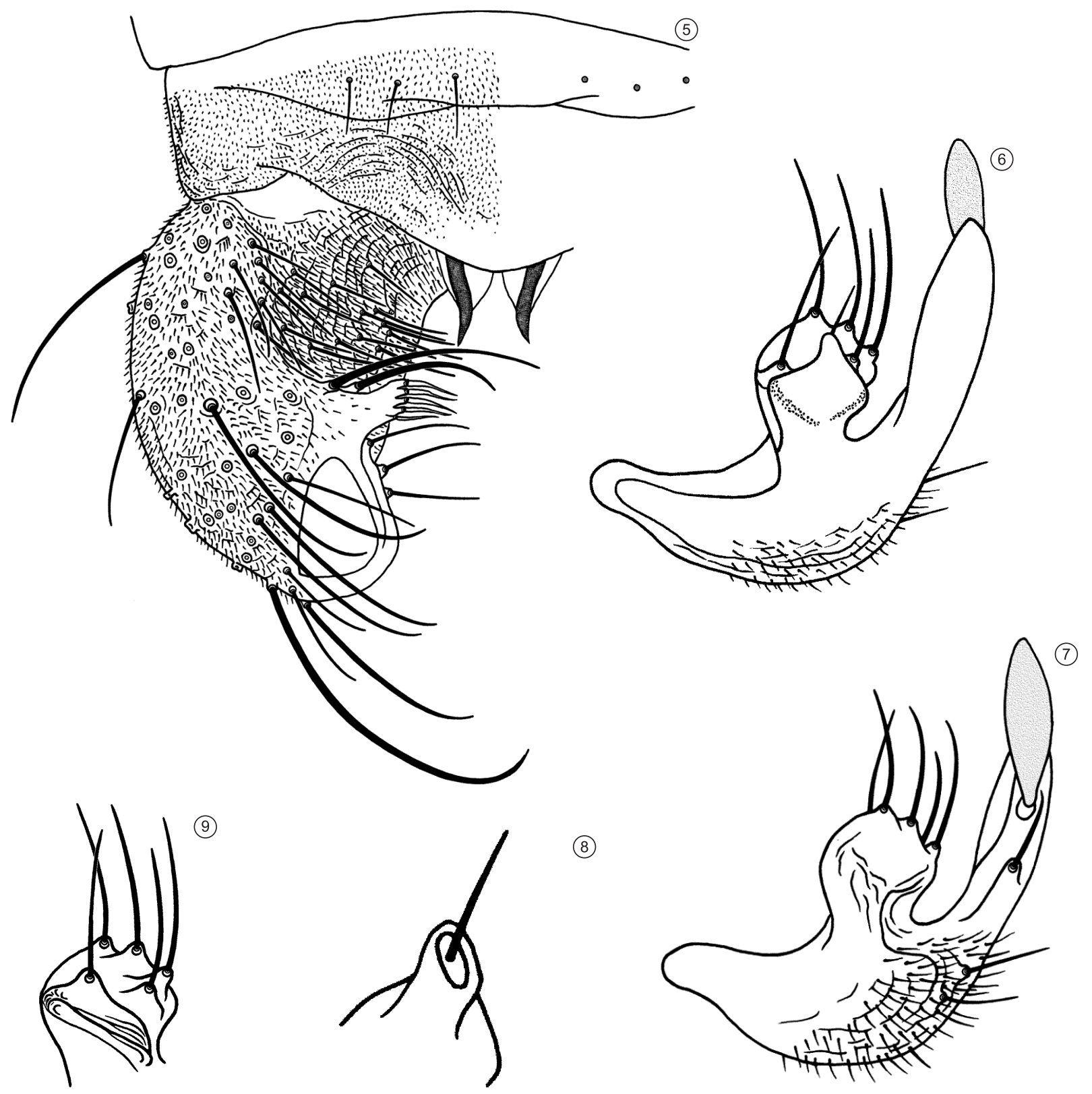

Figures 5-9. Djalmabatista scopulata sp. n., male. 5) Hypopygium, dorsal view; 6) Gonostylus, dorsal view; 7) Gonostylus, ventral view; 8) Dorsal apex of median projection of gonostylus, ventral view; and 9) Ventral apex of median projection of gonostylus, dorsal view.

Comb with 10-11 setae, shortest seta 25-27 $\mu$ m long, longest 46$50 \mu \mathrm{m}$. Lengths and proportions of legs as in Table 1 .

Abdomen: As in Figure 3.

Hypopygium (Figures 4-5): Tergite IX with 6-7 setae in single posterior row. Phallapodeme 102-105 $\mu \mathrm{m}$ long. Gonocoxite 145$148 \mu \mathrm{m}$ long; with 19-21 $\mu \mathrm{m}$ long, 15-18 $\mu \mathrm{m}$ wide, subrectangular projection on inner margin, with apical brush of flattened setae. Gonostylus (Figures 6-9) 82-93 $\mu \mathrm{m}$ long; with rounded outer corner; with median inner projection, 32-36 $\mu \mathrm{m}$ long, 14-15 $\mu \mathrm{m}$ wide at base, 21-22 $\mu \mathrm{m}$ wide at apex; apically split in dorsal, membranous bluntly triangular lobe, with single setae ventrally (Figure 8) and club-shaped, ventral lobe, with 5 strong setae on dorsal surface (Figure 9), megaseta lanceolate, 25-29 $\mu \mathrm{m}$ long, 7-9 $\mu \mathrm{m}$ wide at its widest part, crista dorsalis along inner margin and apex of the distalmost part of gonostyle, $8-9 \mu \mathrm{m}$ long
Table 1. Length (in $\mu \mathrm{m}$ ) and proportions of legs of Djalmabatista scopulata sp. n., male $(\mathrm{n}=2)$.

\begin{tabular}{cccc}
\hline & $\mathbf{p}_{1}$ & $\mathbf{p}_{2}$ & $\mathbf{p}_{3}$ \\
\hline $\mathrm{fe}$ & $576-594$ & $610-659$ & $558-562$ \\
$\mathrm{ti}$ & $796-846$ & $711-734$ & $835-883$ \\
$\mathrm{ta}_{1}$ & $565-567$ & $466-475$ & $522-544$ \\
$\mathrm{ta}_{2}$ & $245-247$ & $194-205$ & $272-274$ \\
$\mathrm{ta}_{3}$ & $166-167$ & $130-139$ & $178-198$ \\
$\mathrm{ta}_{4}$ & $104-112$ & $85-92$ & $108-126$ \\
$\mathrm{ta}_{5}$ & $90-92$ & $81-90$ & $92-99$ \\
$\mathrm{LR}$ & $0.67-0.71$ & $0.65-0.66$ & $0.62-0.63$ \\
$\mathrm{BV}$ & $3.20-3.26$ & $3.46-3.75$ & $2.85-2.94$ \\
$\mathrm{SV}$ & $2.42-2.55$ & $2.83-2.94$ & $2.64-2.67$ \\
$\mathrm{BR}$ & $2.2-2.5$ & $2.4-3.1$ & $2.4-3.1$ \\
\hline
\end{tabular}


apically, ventral subapical seta 14-16 $\mu \mathrm{m}$ long. HR 1.56-1.81. HV 3.51-3.77.

Female, pupa, larva, and egg mass: Unknown.

Distribution and biology: The species was taken in a light trap situated close to a small stream in Nova Xavantina in Central Brazil. The stream where the specimens were collected is a tributary to the Rio das Mortes, that forms the AraguaiaTocantins basin.

\section{Acknowledgements}

We are indebted to Dr. Luiz C. Pinho for sending us the material. Gladys Ramirez made the slide preparations.

\section{References}

ASHE, P. \& O'CONNOR, J.P. 2009. A world catalogue of Chironomidae (Diptera). Part 1. Buchonomyiinae, Chilenomyiinae, Podonominae, Aphroteniinae, Tanypodinae, Usambaromyiinae, Diamesinae, Prodiamesinae and Telmatogetoninae. Irish Biogeographical Society and National Museum of Ireland, Dublin, 445p.

CARRARO, V.M., OLIVEIRA, S.J. \& REGO, L.E.P. 1992. Sobre uma nova espécie neotrópica do gênero Djalmabatista Fittkau, 1968 (Diptera, Chironomidae). Mem. Inst. Oswaldo Cruz 87(Suppl. 1):57-60.

CHAUDHURI, P.K. \& DEBNATH, R.K. 1983. Studies of Indian Tanypodinae (Diptera: Chironomidae). Genus Procladius Skuse. Zool. Jahrb. Abt. Syst. Ökol. Geogr. Tiere 110:111-123.

CRANSTON, P.S. \& MARTIN, J. 1989. Family Chironomidae. In Catalog of the Diptera of the Australasian and Oceanic Regions (N.L. Evenhuis, ed.). Bishop Museum Press, Honolulu and E.J. Brill, Leiden, p.252-274.

DOITTEAU, G. \& NEL, A. 2007. Chironomid midges from early Eocene amber of France (Diptera: Chironomidae). Zootaxa 1404:1-66.

FITTKAU, E.J. \& MURRAY, D.A. 1986. 5. The pupae of Tanypodinae (Diptera: Chironomidae) of the Holarctic Region - Keys and diagnoses. In Chironomidae of the Holarctic Region: keys and diagnoses. Part 2. Pupae (T. Wiederholm, ed.). Ent. Scand., Suppl. 28:31-113.

FITTKAU, E.J. \& ROBACK, S.S. 1983. 5. The larvae of Tanypodinae (Diptera: Chironomidae) of the Holarctic Region - Keys and diagnoses. In Chironomidae of the Holarctic Region: keys and diagnoses. Part 1. Larvae (T. Wiederholm, ed.). Ent. Scand., Suppl. 19:33-110.

FITTKAU, E.J. 1968. Eine neue Tanypodinae-Gattung, Djalmabatista (Chironomidae, Diptera) aus dem brasilianischen Amazonasgebiet. Amazoniana 1(4):327-349.
FREEMAN, P. 1955. A study of the Chironomidae (Diptera) of Africa south of the Sahara. I. Bull. Brit. Mus. Nat. Hist. (Ent.) 4:1-67.

JOHANNSEN, O.A. 1908. New North American Chironomidae. In 23rd report of the State Entomologist on injurious and other insects of the State New York, 1907 (E.P. Felt, ed.). Bull. N. Y. St. Mus. 124:264-285.

MURRAY, D.A. \& FITTKAU, E.J. 1989. 5. The adult males of Tanypodinae (Diptera: Chironomidae) of the Holarctic Region - Keys and diagnoses. In Chironomidae of the Holarctic Region. Keys and diagnoses. Part 3. Adult males (T. Wiederholm, ed.). Ent. Scand., Suppl. 34:37-123.

OLIVEIRA, S.J. de \& CARRARO, V.M. 1997. Nova espécie neotrópica do gênero Djalmabatista Fittkau, 1968 (Diptera, Chironomidae). Entomol. y Vect. 4:3-8.

PAGGI, A.C. 1985. Formas imaginales y preimaginales de Quironomidos (Diptera: Tanypodinae). V. Djalmabatista lacustris sp. nov. Rev. Soc. Ent. Argentina 43:75-83.

ROBACK, S.S. \& COFFMAN, W.P. 1977. New records of probable Djalmabatista species from eastern North America and Venezuela (Chironomidae: Tanypodinae). Proc. Acad. Nat. Sci. Philad. 128:49-54.

ROBACK, S.S. \& TENNESSEN, K.J. 1978. The immature stages of Djalmabatista pulcher [= Procladius (Calotanypus) pulcher (Joh.)]. Proc. Acad. Nat. Sci. Philad. 130:11-20.

ROBACK, S.S. 1971. The adults of the subfamily Tanypodinae (= Pelopiinae) in North America (Diptera: Chironomidae). Monogr. Acad. Nat. Sci. Philad. 17:1-410.

ROBACK, S.S. 1989. The larval development of Djalmabatista pulcher (Joh.) (Diptera: Chironomidae: Tanypodinae). Proc. Acad. Nat. Sci. Philad. 141:73-84.

SÆTHER, O.A. \& ANDERSEN, T. 2000. Djalmabatista reidi (Freeman) comb. n. and Lepidopelopia annulator (Goetghebuer), two interesting macropelopine tanypods from Ghana (Diptera: Chironomidae). In Late 20th Century Research on Chironomidae: an Anthology from the 13th International Symposium on Chironomidae (O. Hoffrichter, ed.). Shaker Verlag, Aachen, p.209-220.

SÆTHER, O.A. 1969. Some Nearctic Podonominae, Diamesinae and Orthocladiinae (Diptera: Chironomidae). Bull. Fish. Res. Bd Canada 107:1-154.

SÆTHER, O.A. 1980. Glossary of chironomid morphology terminology (Diptera: Chironomidae). Ent. Scand., Suppl. 14:1-51.

Received 30/06/2010

Revised $31 / 08 / 2010$

Accepted 28/09/2010 